\title{
Pola Komunikasi Orang Tua Terhadap Anak Dalam Seleksi Menonton Televisi di Ngentak Sapen, Catur Tunggal, Depok, Yogyakarta.
}

\author{
Haryanto Hasan \\ Progam Pascasarjana Progam Studi Interdisciplinary Islamic Studies, \\ Konsentrasi Kajian Komunikasi Dan Masyarakat Islam UIN SunanKalijaga. \\ haryhasan.albachsin94@gmail.com
}

\begin{abstract}
Currently television as one of the modern communication media that very rapid development. This development certainly has positive and negative effects in accordance with the events broadcast by this media.This research uses qualitative research methods, that is to produce data in the form of written or oral words of the people and behavior to be observed, and phenomenological approach intended to know and understand as well as describe what happened in research place clearly and in detail by collecting as much data as possible about parents' communication to children in television viewing selection and parental barriers in communication with children in NgentakSapen, Catur Tunggal, Depok, Yogyakarta Researchers concluded that the pattern of parent communication with children in the selection of watching television runs well although only some of the parents who realize the magnitude of the influence of television for the development of children, especially in speech and behavior, and communication barriers parents with children is not too difficult, although sometimes children like to be angry, denied when ruled, never understood when advised but anyway obstacles that parents can understand it and find a solution to change the barriers and do not forget always give advice to the attitude of such a child does not happen again.
\end{abstract}

Keywords: Communication Patterns, Parents, Child, television.

\begin{abstract}
Abstrak
Saat ini televisi sebagai salah satu media komunikasi modern yang perkembangannya sangat pesat sekali. Perkembangan ini tentu memiliki efek-efek yang positif dan negatif sesuai dengan acara-acara yang disiarkan oleh media ini. Penelitian ini menggunakan metode penelitian kualitatif, yaitu menghasilkan data berupa kata-kata tertulis atau lisan dari orang-orang dan prilaku yang akan diamati., dan pendekatan fenomenologis yang dimaksudkan untuk mengetahui dan memahami sekaligus menggambarkan apa saja yang terjadi di tempat penelitian dengan jelas dan terinci dengan cara mengumpulkan data sebanyak mungkin mengenai komunikasi orang tua terhadap anak dalam seleksi menonton televisidan hambatan orang tua dalam komunikasi dengan anak di Ngentak Sapen, Catur Tunggal, Depok, Yogyakarta. Peneliti menyimpulkan bahwa pola komunikasi orang tua dengan anak dalam seleksi menonton televisi berjalan dengan
\end{abstract}


baik walaupun hanya sebagian dari para orang tua yang menyadari besarnya pengaruh televisi bagi perkembangan anak, terutama dalam ucapan dan perilaku, dan hambatan komunikasi orang tua dengan anak tidak terlalu sulit walaupun terkadang anak suka marah, membantah bila diperintah, tidak pernah mengerti ketika dinasehati tapi bagaimanapun hambatan tersebut orang tua bisa memahaminya dan mencarikan solusi untuk mengubah hambatan tersebut dan tidak lupa selalu memberikan nasehat agar sikap anak yang demikian tidak kembali terjadi.

Kata Kunci: Pola Komunikasi, Orang Tua, anak, Televisi

\section{Pendahuluan}

Anak merupakan kelompok yang paling rawan terhadap bahaya televisi. Karena anak merupakan kelompok yang mudah untuk menyerap informasi apa saja dan tidak dapat memfilter atau membedakan mana informasi yang baik dan mana informasi yang kurang baik. Data dari hasil penelitian Yayasan Kesejahteraan Anak Indonesia (YKAI) dan Litbang Departemen Penerangan tahun 1993 tentang tayangan untuk anak-anak di televisi, terungkap 52 persen adalah adegan antisosial dan hanya 48 persen yang proposional. Adegan antisosial itu mencangkup perkelahian, berbagai jenis kekerasan, gangguan terhadap orang lain serta sadisme. ${ }^{1}$

Pada saat ini televisi sebagai salah satu media komunikasi modern yang perkembangannya sangat pesat sekali. Perkembangan ini tentu memiliki efek-efek yang positif dan negatif sesuai dengan acara-acara yang disiarkan oleh media ini. Televisi sebagai salah satu produk kemajuan peradaban adalah ibarat sebuah pisau bermata yang bisa digunakan untuk hal yang bermanfaat dan bisa digunakan untuk hal yang membuat madhorot bagi manusia.

Televisi juga merupakan bagian dari perlengkapan rumah yang kerap kali dicerca namun sering pula dicintai secara berlebihan. Dalam hal ini televisi sangat besar pengaruhnya terhadap anak dan komunikasi dalam keluarga. Banyak contoh kasus yang terjadi misalnya komunikasi keluarga terganggu karena keluarga itu terlalu sering menonton televisi sehingga lupa waktu. Memang televisi sangat berpengaruh dalam kehidupan sehari-hari, hingga sejauh ini pengaruh terhadap kegagalan komunikasi masih belum diketahui secara pasti. Suatu hal yang tidak dapat disangkal, bahwa acara-acara yang disuguhkan televisi dapat mempengaruhi perkembangan pola pikir anak. ${ }^{2}$

Pengaruh tersebut ditimbulkan beberapa film yang menyajikan prilaku kekerasan, dan percintaan yang sebenarnya hal ini tidak mendidik bagi anak, selain itu pula kemungkinan anak akan mengenal kejahatan, teror dan berbagai kejadian menyimpang lainnya. Bahkan waktu yang dihabiskan oleh anak-anak untuk menonton televisi cukup banyak memprihatinkan, rata-rata tidak kurang dari 3 jam sehari. Bahkan ada penelitian

${ }^{1}$ Wawan Kuswandi, Komunikasi Massa Sebuah Analisis Media Televisi Jakarta (PT Renika Cipta, 1996), 62

${ }^{2}$ Alex Sobur., Komunikasi Orang Tua dan Anak,(Bandung: Angkasa, 1985), 50 
lain yang mengatakan bahwa anak-anak dalam sehari tidak kurang dari 7 jam waktu yang digunakan untuk menonton televisi. Tayangan yang mereka tonton kebanyakan kartun tetapi tema dan perilakunya film tersebut menggambarkan perilaku orang dewasa. Ambil contoh: Naruto, Sinchan, Doraemon, Avatar, Drama sinetron dan beberapa film lain yang isinya semuanya memperlihatkan kekerasan dan perilaku yang tidak pantas dilakukan oleh seorang anak kecil. Mereka semua mengajarkan bahwa permasalahan yang ada penyelesaiannya adalah melalui kekerasan, entah itu berkelahi, main pukul atau kata-kata kasar yang semuanya mudah ditiru oleh anak-anak.

Namun yang menjadi kendala saat ini adalah kesibukan orang tua dan sedikitnya waktu yang ada untuk mendampingi serta mengawasi anak merupakan salah satu faktor ketidaktahuan orang tua terhadap perkembangan anaknya, sehingga pada akhirnya orang tualah yang menyerahkan pengasuhan anak kepada media televisi. Apalagi orang tua tidak ada waktu lagi untuk menyeleksi tontonan mana yang selektif dan pantas ditonton anak.

Menonton televisi secara terus menerus bisa berdampak kurang baik bagi anak, namun melarang anak untuk tidak menonton televisi juga kurang baik, yang lebih bijaksana adalah mengontrol tayangan televisi bagi anak-anak. Setidaknya memberikan pemahaman kepada anak mana yang bisa mereka tonton dan mana yang tidak boleh dalam hal ini orang tua perlu mendampingi anak-anaknya saat menonton televisi, memberikan berbagai pemahaman kepada anak-anak tentang suatu tayangan yang sedang disaksikan. Selain sebagai sarana membangun komunikasi yang efektif dengan anak, hal ini bisa mengurangi dampak negatif televisi bagi anak. Oleh sebab itulah kebiasaan mengonsumsi tayangan televisi secara sehat ini mesti dimulai sejak anak di usia dini.

Peran serta orang tua memang sangat diperlukan dalam memperhatikan perkembangan anaknnya melalui pendidikan yang lebih baik, terlebih lagi orang tua pun harus bisa membimbing serta menjauhkannya dari pengaruh yang negatif dalam menonton tayangan televisi, sehingga anak dalam prilakunya akan mudah untuk dibina, karena keberadaan anak sebagai generasi penerus yang berkemampuan tinggi diberbagai bidang kegiatan dimasa yang akan datang sangat diharapkan, dan jangan sampai orang tua menjadikan anaknya terpengaruh lebih dalam lagi akibat terlalu sering menonton televisi sendirian, tentunya hal ini akan membuat anak semakin pasif dan lemah dalam beraktivitas dan berkreasi. Sebagaimana Allah SWT sendiri memperingatkan agar kita tidak meninggalkan generasi penerus yang lemah, baik fisik mapun mentalnya.

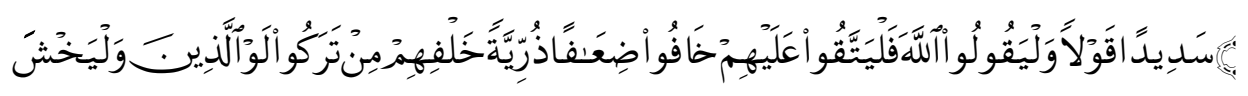

Artinya:Dan hendaklah takut kepada Allah orang-orang yang seandainya meninggalkan dibelakang mereka anak-anak yang lemah, yang mereka khawatir terhadap (kesejabteraan) mereka. 
oleh sebab itu hendaklah mereka bertakwa kepada Allah dan hendaklah mereka mengucapkan perkataan yang benar. ${ }^{3}$

Terkait mengenai hal ini, penulis merasa sangat tertarik untuk melakukan penelitian lebih dalam lagi berkenaan dengan komunikasi orang tua kepada anaknya dalam upaya menseleksi tayangan televisi dan hambatan orang tua dalam komunikasi dengan anak, khususnya di Ngentak Sapen, Catur Tunggal, Depok, Yogyakarta. dan menjadikannya sebagai bahan kajian dalam penelitian ini.

\section{MetodePenelitian}

Penelitian ini merupakan jenis penelitian kualitatif yang digunakan sebagai prosedur penelitian yang menghasilkan data berupa kata-kata tertulis atau lisan dari orang-orang dan prilaku yang akan diamati. ${ }^{4}$ Pendekatan yang digunakan dalam penelitian ini adalah fenomenologis yang dimaksudkan untuk mengetahui dan memahami sekaligus menggambarkan apa saja yang terjadi di tempat penelitian dengan jelas dan terinci dengan cara mengumpulkan data sebanyak mungkin mengenai komunikasi orang tua terhadap anak dalam seleksi menonton televisi dan hambatan orang tua dalam komunikasi dengan anakdi Ngentak Sapen, Catur Tunggal, Depok, Yogyakarta.

Subyek yang akan diteliti adalah orang tuanya yang berdomisili di Lingkungan Ngentak Sapen, Catur Tunggal, Depok, Yogyakarta, sebanyak 5 orang tua sebagai responden yang diambil dan 5 orang anak sebagai informennya. Oleh sebab itu penentuan subyek penelitian ini adalah menggunakan Sampel bertujuan (Porposive Sampling) yaitu dengan kriteria;

a. Orangtua Kandung

b. Sudah berkeluarga lebih dari 10 tahun

c. Mempunyai anak minimal berusia 8-12 tahun

d. Keluarga Muslim

e. Bermata percaharian sebagai; PNS, Pedagang dan Buruh

\section{Penentuan Latar Penelitian}

Menurut Moleong, seorang peneliti hendaknya harus memperhatikan latar penelitiannya, apakah terbuka atau tertutup, apakah sebagai peneliti yang dikenal atau yang tidak dikenal, sehingga dengan hal ini peneliti dapat tahu dan menempatkan diri dengan baik dalam mengali dat secara optimal. ${ }^{5}$ Penelitian ini peneliti akan mempergunakan latar tertutup karena yang diteliti adalah komunikasi orang tua terhadap anak dalam seleksi menonton televisi. Hal ini dilakukan karena peneliti ingin menjalin keakraban dengan subjek yang diteliti, juga waawancara yang menedalam tentang komunikasi orang tua terhadap anak.

3Departemen Agama RI, Alquran dan Terjemah, (Bandung: CV. Gema Risalah Press, 1993),

${ }^{4}$ Lexy J. Moleang, Metode Penelitian Kualitatif, (Bandung: PT Remaja Rosdakarya, 1999), 3

${ }^{5}$ AndiBulaeng, Metode Penelitian Komunikasi Kontemporer, (Yogyakarta : Andi, 2004), 94 


\section{Teknik Pengumpulan Data}

Dalam pengumpulan data, peneliti menggunakan teknik wawancara sebagai alat pengumpul data yang utama, sedangkan observasi sebagai alat pendukung pengumpulan data dalam penelitian ini. Data yang akan dikumpulkan melalui teknik wawancara, yaitu strategi pengumpulan data yang digunakan dalam penelitian kualitatif mempunyai ciri yaitu menggunakan metode wawancara yang terstruktur pada ceklist yang digunakan. Data yang digali dari teknik ini adalah:

a. Berapa kali dalam seminggu bapak atau ibu mendampingi anak saat mereka menonton televisi?

b. Bagaimana pendapat bapak atau ibu mengenai tayangan televisi saat ini?

c. Menurut bapak atau ibu bagaimana tayangan yang baik untuk dapat ditonton oleh anak-anak?

d. Apakah bapak ibu pernah menyeleksi tayangan yang pantas di tonton anak?

e. Berapa banyak waktu yang digunakan anak bapak ibu untuk menonton televisi dalam sehari?

f. Adakah pengaruhnya tayangan televisi bagi perkembangan anak bapak ibu, dan komunikasi dalam keluarga?

g. Apakah adik pernah didampingi oleh bapak atau ibu saat menonton televisi?

h. Tayangan apa yang adik gemari?

Selanjutnya teknik yang dipergunakan adalah teknik observasi sebagai alat pengumpulan data adalah untuk memungkinkan peneliti mempelajari tingkah laku secara langsung sebagaimana tingkah laku itu terjadi, dan pengamatan secara langsung terhadap subjek maupun objek penelitian yang meliputi:

a. Mengamati komunikasi orang tua dan anaknya dalam kehidupan sehari-hari.

b. Mengamati sikap anak dalam kesehariannya

\section{Pengabsahan Data}

Pengabsahan data adalah untuk menjamin bahwa semua yang diamati dan diteliti penulis sesuai dengan yang sesungguhnya dan memang terjadi. Hal ini dilakukan penulis untuk memelihara dan menjamin bahwa data ataupun informasi yang dihimpun itu benar. Untuk memperoleh data yang valid, penulis menggunakan teknik triangulasi sumber. ${ }^{6}$ Pengecekan sumber data tersebut dilakukan melalui pengamatan dan wawancara sebagai alat pendukung untuk meneliti kebenaran suatu jawaban dengan data empiris terhadap komunikasi yang dilakukan oleh orang tua terhadap anaknya.

\section{Analisis Data}

Teknik analisis data yang penulis gunakan dalam penelitian ini adalah induktif, proses analisis ini dilakukan secara bersamaan. Dengan demikian penulis menggunakan

${ }^{6}$ Rachmat Kriyantono, Teknik Praktis Riset Komunikasi, Jakarta: Kencana Prenada Media Group, 2006, h. 71. 
teknik analisis yang dikembangkan oleh Miles dan Huberman yang dikutip Qodir ${ }^{7}$ bahwa teknik analisis data dalam penelitian kualitatif dapat dilakukan melalui tahapan yaitu: (a) Data Collection, (b) Data Reduction (pengurangan data), (c) Data Display penampilan data, (d) Conclusion (menarik kesimpulan dari data yang diperoleh).

\section{Pembahasan Dan Hasil Penelitian}

Dari hasil wawancara dan observasi yang peneliti lakukan di Ngentak Sapen, Catur Tunggal, Depok, Yogyakartahanya sebagian dari warga yang peneliti jadikan sebagai sampel yakni berjumlah 5 keluarga dengan kriteria yang ditentukan diantaranya orang tua kandung, memiliki anak minimal usia 8-12 tahun dan bermata pencaharian sebagai PNS, Buruh dan Pedagang. Untuk lebih jelasnya maka peneliti menguraikannya dalam bentuk tabel:

\begin{tabular}{|c|c|c|c|c|}
\hline No & Nama Keluarga & Jumlah Anak & Usia Anak & Pekerjaan \\
\hline 1 & $\begin{array}{l}\text { Ayah: SKT } \\
\text { Ibu : MRH } \\
\text { Anak : LKM }\end{array}$ & 3 (Tiga) Orang & 9 Tahun & PNS \\
\hline 2 & $\begin{array}{l}\text { Ayah : STN } \\
\text { Ibu : URN } \\
\text { Anak : FSA }\end{array}$ & 2 (Dua) Orang & 11 Tahun & Pedagang \\
\hline 3 & $\begin{array}{l}\text { Ayah : GDR } \\
\text { Ibu : MSR } \\
\text { Anak : AS }\end{array}$ & 1 (Satu) Orang & 12 Tahun & Swasta \\
\hline 4 & $\begin{array}{l}\text { Ayah : MH } \\
\text { Ibu : WY } \\
\text { Anak : WDT }\end{array}$ & 1 (Satu) Orang & 10 Tahun & Wiraswasta \\
\hline 5 & $\begin{array}{l}\text { Ayah : RLN } \\
\text { Ibu : SFY } \\
\text { Anak : IBN } \\
\end{array}$ & 3 (Tiga) Orang & 9 Tahun & Buruh \\
\hline
\end{tabular}

\section{Penyajian Data}

\section{Keluarga Bapak SKT dan Ibu MRH}

Bapak SKT adalah sepasang keluarga yang harmonis penuh dengan perhatian dan kasih sayang baik terhadap keluarga terlebih lagi terhadap perkembangan anaknya, bapak SKT sendiri adalah seorang Pegawai Negeri Sipil yang mempunyai 3 orang anak, yaitu pertama DD berusia 15 tahun, kedua adalah LKM yang berusia 9 tahun dan yang ke tiga NE berusi 3 tahun. Sedang ibu MRH adalah seorang ibu rumah tangga yang juga

${ }^{7}$ Abdul Qodir, Metodologi Riset Kualitatif (Panduan Dasar Melakukan Penelitian Kualitatif), Palangka Raya, t.np., 1999. 77. 
berprofesi sebagai pedangan yang berjualan dirumah karena kebetulan keluarga bapak SKT mempunyai sebuah toko. Sebagai orang tua yang menginginkan anak-anaknya tumbuh dan berkembang dengan baik bapak SKT dan ibu MRH mempunyai cara tersendiri dalam membimbing anak-anaknya. SKT dan MRH tidak menginginkan anakanaknya terjerumus ke hal yang tidak baik sehingga mempengaruhi prilaku dalam kehidupannya sehari-hari, terutama prilaku yang mudah sekali anak contoh dan kebanyakan dari hasil menonton televisi.

Sebagaimana Penelitian yang peneliti lakukan dalam wawancara dengan keluarga bapak SKT dan MRH mengatakan bahwa:

"Tayangan televisi saat ini banyak menyajikan acara yang bervariasi yang terkadang anak-anak pun larut dalam suasana menonton televisi yang dapat membuat mereka lupa untuk belajar, dan beberapa acara televisi yang dapat dikatakan kurang pas untuk di tonton anak, seperti halnya sinetron yang sifatnya tidak mendidik, film-film kartun yang hanya menggambarkan angan dan imajinasi serta acara-acara musik yang mempertontonkan tarian yang tidak baik dengan pakaian yang kurang pantas, yang sebenarny a berdampak tidak baik bagi anak."

Wawancara tersebut di atas, menjelaskan betapa besarnya pengaruh televisi terhadap prilaku-prilaku anak terlebih lagi prilaku yang tidak baik dan tidak mendidik tersebut disajikan dalam acara-acara yang menarik dan tentunya hal tersebut agar anak dapat menontonnya. Tetapi yang perlu diperhatikan adalah bagaimana peran orang tua terhadap cara penyajian akan tontonan tersebut setidaknya ada batas waktu yang diberikan orang tua terhadap anak untuk menonton televisi. Selain itu juga komunikasi dengan anak harus tetap berjalan dengan cara orang tua harus senantiasa menjelaskan terhadap karakter, prilaku dan isi pesan dari acara yang dilihat anak, yang tujuannya agar anak mengerti dan tidak menerima begitu saja akan pesan yang disampaikan acara tersebut. Untuk itulah pentingnya orang tua mendampingi anak dalam hal memberikan yang terbaik dan memilihkan tayangan yang baik untuk anak.

Dari hasil wawancara peneliti dengan ibu MRH:

"Dalam hal menonton televisi anak saya termasuk anak yang suka dan sering menonton televisi, tetapi saya selaku orang tua harus dapat memantau babkan untuk acara yang tidak baik saya selalu melarang agar anak tidak menonton. Adapun waktu untuk menonton televisi bisa hampir setiap hari, tapi kalau waktunya untuk belajar maka saya selalu mengingatkan mereka dan kegiatan menonton sementara dihentikan sampai selesai belajarnya, tetapi untuk hari libur bisanya sampai jam 9 tetapi untuk hari-hari biasa hanya sampai jam 19.30 tidak sampai larut malam, karena saya tidak memperbolebkan mereka menonton terlarut malam. Kalaupun pengarub terbadap sikap anak dari menonton televisi sepertinya tidak ada, karena saya selalu mengarahkan anak saat mereka menonton televisi agar mereka bisa membedakan mana yang baik dan mana yang tidak baik." ".

Komunikasi dalam keluarga alhamdulillah sangat terjalin dengan baik dalam suasana apapun terlebih lagi saat menonton televisi bersama-sama, hal yang demikian

${ }^{8}$ Wawancara dengan bapak SKT, tanggal 04 Januari 2018

${ }^{9}$ Wawancara dengan ibu MRH, tanggal 04 Januari 2018 
selalu saya lakukan tentunya untuk kebaikan anak juga kan, tutur bapak SKT dalam wawancaranya, dalam wawancara yang sama pun bapak SKT mengatakan:

"Tayangan yang sehat dan baik untuk anak adalah yang bersifat mendidik dan tayangan yang memperlihatkan berbagai macam keablian yang salah satunya adalah tayangan olah raga yang tujuannya agar anak cinta dan suka akan olah raga dan mengikuti olah raga yang dilihatnya, kalaupun untuk tayangan sinetron itu juga harus sinetron yang bisa mendidik. Untuk masalah menseleksi acara televisi dan mendampingi anak saat mereka menonton saya termasuk jarang tetapi saya mengharapkan yang baik-baik, kalaupun ada acara yang menurut saya kurang baik saya larang anak untuk menontonnya dan babkan saya matikan televisinya."

Dari hasil wawancara di atas diketahui ada kekhawatiran orang tua terhadap perkembangan anaknya baik secara kejiwaan ataupun secara mental terlebih lagi akan prilaku anak yang mudah sekali terpengaruh dengan lingkungannya bahkan dengan sesuatu yang dilihatnya dan merupakan hal yang baru baginya, untuk itulah diperlukannya peran orang tua dalam hal mendampingi anak dan selalu mengajaknya untuk berkomunikasi saat sedang menonton ataupun tidak, tentunya hal ini dilakukan agar anak dapat menikmati tayangan yang baik dan tentunya akan berpengaruh juga untuk kepribadiaannya.

\section{Keluarga bapak STN da Ibu URN}

Keluarga bapak STN dan ibu URN adalah keluarga yang sederhana, pekerjaan bapak STN adalah sebagai pedagang sedangkan ibu adalah sebagai ibu rumah tangga, beliau mempunyai 2 orang anak FS yang berusia 11 tahun dan $\mathrm{CN}$ berusia 5 tahun, sebagaimana wawancara peneliti dengan bapak STN mengatakan:

"Tayangan televisi saat ini banyak negatifnya karena didomisili oleh sinetron yang mana sinetron tersebut banyak menghalalkan unsur kekerasan dan kesenjangan sosial masyarakat makanya banyak sekali tayangan televisi yang tidak memberikan pesan dan kesan yang baik bagi penontonnya terutama sekali pada anak-anak yang sebenarnya secara tidak langsung televisi dapat mengajarkan anak tentang pengetahuan yang tidak didapatinya di tempat dia sekolah tapi sangat disayangkan tayangan televisi saat ini tidak dapat memberikan nilai-nilai positif bagi anak khusunya."11

Oleh sebab itulah dari hasil wawancara menyatakan kiranya orang tua dapat mendampingi anak saat mereka menonton televisi, dan jangan menjadikan mereka pasif yakni hanya sekedar menonton tanpa komunikasi, untuk itulah proses komunikasi dalam keluarga harus berjalan dengan baik dan tidak ada yang namanya miskomunikasi. Selain itu peneliti pun mewawancarai ibu URN, beliau mengatakan:

"Mendampingi dan melakukan komunikasi dengan anak sering saya lakukan walupun anak jarang sekali menonton televisi, tapi pada saat mereka nonton saya selalu hadir besama mereka dan menonton bersama-sama dan dalam memilih tayangan saya pun selalu menseleksi tayangan yang kirakira pas dan baik untuk ditonton oleh anak tentunya bersifat mendidik kecerdasan anak, baik itu

${ }^{10}$ Wawancara dengan bapak SKT, tanggal 05 Januari 2018

${ }^{11}$ Wawancara dengan Bapak STN pada tanggal 8 Januari 2018 
yang berkenaan dengan film kartun, kuis-kuis, maupun film-film sinetron tapi yang mengandung unsur pengetabuan bagi anak, apa itu pengetahun agama maupun pengetabuan umum." "12

Melakukan komunikasi dengan anak saat menonton televisi merupakan hal efektif dalam menyampaikan pesan, karena dengan media televisi anak akan dengan mudah dapat belajar dan mengenal sesuatu yang baru tetapi tentunya orang tua harus dapat memilihkan tayangan yang mendidik. Sebagaimana wawancara peneliti dengan bapak STN dan ibu URN mengatakan:

"Saya selalu sempatkan waktu untuk berkomunikasi dengan anak, karena pada saat menonton televisi itulah saya selalu memberikan penjelasan dan pesan-pesan moral kepada anak melalui tayangan yang dilibatnya yang tujuannya agar anak dapat mengambil hikmah dan pelajaran tentang kehidupan disekitranya yang tentunya akan menjadikan anak selalu berfikir dan mensyukuri terhadap apa yang telah diberikan oleh-Nya saat itu."13

Hasil wawancara peneliti dengan bapak STN dan ibu URN menjelaskan bahwa dalam menonton televisi pun keefektipan komunikasi dalam keluarga harus tetap terjalin baik, karena dengan berkomunikasilah akan ada keterbukanan antara orang tua dan anak, sehingga orang tua akan dengan mudah sekali memberikan masukan, arahan dan nilai-nilai kebaikan pada diri anak sehingga anakpun akan mudah untuk dapat memahami dan mencontohkan hal kebaikan tersebut dalam kehidupannya sehari-hari.

\section{Keluarga GDR dan MSR}

Bapak GDR dan ibu MSR adalah sebuah keluarga yang hanya mempunyai anak 1 yakni AS yang kini berusia 12 tahun dan duduk di bangku sekolah SD kelas 6, bapak GDR dan ibu MSR termasuk orang tua yang sibuk, yakni bapak GDR berprofesi sebagai Devploper sedangkan ibu MSR berdagang gorengan yang warungnya tidak jauh dari rumahnya.Pada saat peneliti berkunjung kerumah bapak GDR tersebut dan melakukan wawancara yang berkaitan dengan komunikasi orang tua terhadap anak dalam seleksi menonton televisi, beliau mengatakan:

"Televisi saat ini memang bisa dikatakan sebagai kebutuban pokok karena saya pribadi masih banyak membutubkan informasi, tapi di lain pibak televisi sebagai hiburan keluarga banyak menampilkan peran-peran yang tidak baik dalam film-film seperti balnya kekerasan fisik, bicara dengan kata-kata kasar, perkelabian yang kesemuanya itu bias saja berdampak kurang baik terhadap masyarakat yang menjadi penontonnya babkan berdampak buruk pada anak baik dalam prilakunya maupun dalam perkataannya terhadap sesamanya atau mungkin lingkungan sekitarnya.Namun sebagai orang tua saya tentunya harus senantiasa menyempatkan diri berkumpul dengan keluarga memantau perkembangan anak menjalin komunikasi yang baik sehingga anak dapat dengan mudahnya bertaya dan bercerita tentang semua yang ia ketabui."'44.

Berdasarkan hasil wawancara di atas, televisi memang banyak menghipnotis peminatnya untuk berlama-lama menonton mulai dari orang tua,remaja bahkan sampai

\footnotetext{
${ }^{12}$ Wawancara dengan ibu URN, 8 Januari 2018

${ }^{13}$ Wawancara dengan ibu URN, tanggal 10 Januari 2018

${ }^{14}$ Wawancara dengan GDR, tanggal 11 Januari 2018
} 
kepada anak-anak, menurut bapak GDR tayangan televisi saat ini banyak memberikan acara yang kurang pas, baik dalam penyajian maupun dalam penyampaiaanya, dan hal sepertu itulah banyak memberikan kesan yang kurang pantas terhadap anak. Oleh karena itu menururnya harus ada bimbingan orang tua terhadap anak saat mereka menonton televisi yang tujuannya adalah untuk mengontrol dan mengarahkan anak.

Sebagaimana penuturan MSR yang melihat dan memperhatikan anaknya AS, ia suka sekali menonton televisi tetapi tidak terlalu sering, hampir tiap hari anak saya menonton televisi muali dari film kartun sampai sinetron dan hal ini tidak saya batasi karena kegiatan anak selalu terpantau, sebagaimana penuturan MSR sebagai berikut:

"Anak saya suka sekali menonton televisi biasanya ia menonton televisi sehabis pulang sekolah, sesudah shalat mahgrib dan isya dan setelah shalat subub waktu-waktu seperti itulah yang sering digunakan anak untuk menonton televisi dan saya selaku orang tua tidak bosan-bosannya selalu memberikan pengartian agar anak tidak terlalu sering menonton telavisi, tapi namanya anak walaupun sudah dinasehati tetap saja tidak diindabkan." 15

Berdasarkan wawancara di atas, AS termasuk anak yang hobi menonton sebagaimana yang dituturkan MSR, dan kebiasan AS menonton televisi tidak pernah dibatasi oleh orang tuanya, tetapi MSR yang melihat keadaan AS seperti itu terkadang menegur dan menasehati agar tidak terlalu sering menonton televisi, tapi hal yang demikian AS tidak selalu menghiraukan.

Wawancara peneliti dengan bapak GDR dan ibu MSR yang berkaitan dengan peran orang tua dalam mendampingi saat menonton televisi bagi keluarga ini memang jarang sekali dilakukan hanya pada waktu luang saja, sebagaimana wawancara yang peneliti lakukan perihal permasalahan tersebut:

"Dalam hal menonton televisi saya jarang sekali mendampingi anak dikarenakan kesibukan dan begitu pula dengan ibunya sibuk dagang tapi bila ada waktu-waktu luang saya gunakan untuk berkumpul dengan keluarga melakukan komunikasi memberi penjelasan dan pengarahan atas tayangan yang di tontonnya dan selalu menseleksi tayangan televisi yang baik untuk ditonton walaupun terkadang anak tidak suka dengan tayangan tersebut, malah ia sempat marah-marah karena tidak bisa diberi pengarahan terhadap film yang dilihatnya." "'6

Dari hasil wawancara tersebut, bapak GDR dan ibu MSR terlihat tidak mempunyai cukup banyak waktu untuk mendampingi anak dan menseleksi acara-acara yang sekiranya baik untuk dilihat anak, hal terkendala dengan kesibukan bapak GDR dan ibu MSR dengan pekerjaannya, tetapi bila dalam suasana libur mereka adakalanya mendampingi anak dan menonton bersama dengan anak serta memberikan arahan dan penjelasan tentang acara yang sedang dilihatnya.

Mengenai tayangan yang baik untuk di lihat anak, dalam kesempatan lainnya peneliti mewawancarai bapak GDR di tempat tinggalnya, dalam wawancara tersebut beliau mengatakan:

\footnotetext{
${ }^{15}$ Wawancara dengan ibu MSR, tanggal 12 Januari 2018

${ }^{16}$ Wawancara dengan bapak GDR, tanggal 13 Januari 2018
} 
"Mengenai tayangan televise saya selaku orang tua mengabrapkan untuk acara-acara anak alabkah baiknya tayangan yang bermanfaat memberikan pengatabuan yng sifatnya mendidik serta waktu tayang yang disesuaikan dengan kegiatan anak. Walaupun saya sibuk, tapi saya tak lupa untuk selalu memantau perkembangan anak dalam setiap kegiatannya. "'7

Hasil wawancara di atas, bahwa bapak GDR walaupun terkadang sibuk dengan pekerjaannya itu, tetapi dalam masalah memilih tayangan untuk anak beliau mengharapkan tayangan yang diperuntukkan untuk anak itu bersifat mendidik, dan bayak memberi manfaat serta pengetahuan yang tujuannya agar pemikiran anak dapat berkembang dengan baik.

\section{Keluarga bapak MH dan ibu WY dengan anak bernama WDT}

Keluarga bapak MH dann ibu WY adalah keluarga sederhana. Bapak MH dan ibu WY mempunyai seorang anak yang bernama WDT yang berusia 11 tahun. Bapak $\mathrm{MH}$ adalah seorang wiraswasta yang bekerja membuat makanan ringan dirumahnya dengan di bantu ibu WR dan dua orang pekerjanya yang sertiap harinya memproduksi makanan ringan tersebut. Saat peneliti mengadakan wawancara dengan bapak $\mathrm{MH}$ dikediamannya beliau mengatakan yang berkaitan dengan komunikasi orang tua terhadap anak dalam seleksi menonton televisi:

"Komunikasi dalam keluarga bagi saya adalah bal yang penting karena dengan berkomunikasi yang baik hubungan dengan keluarga akan terlihat lebih harmonis, oleh karena itu komunikasi selalu dijaga dan alhmadulillah berjalan dengan baik antara saya dengan isteri, saya dengan anak maupun dengan lingkungan masyarakat sekitar. Adapun tanggapan saya berkenaan dengan tayangan televise saat ini sangatlah tidak mendidik bagi anak tidak ada hal-hal positifnya yang dapat ditiru oleh anak, kebanyakan acara yang ditayangan kisah-kisah drama asmara dan konflik dalam keluarga yang kesemua hal tersebut tidak satupun kebaikan yang dapat ditiru oleh anak." "18.

Berdasarkan hasil wawancara dengan bapak $\mathrm{MH}$, bahwa komunikasi dalam keluarganya sangatlah penting karena hal tersebut mendukung terbinanya keluarga yang harmonis, terlebih lagi komunikasi terkait dengan acara-acara televise yang suka ditonton anak yang kebanyakan mempertontonkan hal-hal yang negatif dan kisah orang dewasa, dan kondisi seperti inilah dimana bapak MH mencoba menjalin komunikasi yang lebih baik lagi terutama dengan anak.

Tayangan televisi yang beragam memang sangat disukai oleh anak, mulai dari acara film kartun sampai sinetron tak jarang anak pun menyukainya, sebagaimana wawancara dengan bapak MH:

"Anak saya WDT yang berusia 11 tabun kebetulan memang suka menonton televise yang acaranya itu pun kartun seperti Doraemon, Casper, sinetron dan lain-lain, tapi saya selaku orang tua baike ibunya pun jarang sekali memantau kegiatan anak dalam menonton televisi dan saya juga jarang

\footnotetext{
${ }^{17}$ Wawancara dengan bapak GDR, tanggal 14 Januari 2018

${ }^{18}$ Wawancara dengan bapak MH pada tanggal 16 Januari 2018
} 
36 |Jurnal Dakwah dan Komunikasi, Vol. 3, No. 1, 2018

sekali melalukan komunikasi dengan anak berkenaan dengan film atau tayangan yang sedang anak lihat". ${ }^{19}$

Hasil wawancara tersebut menyatakan walaupun bapak $\mathrm{MH}$ dalam kesehariannya senantiasa menjalin komunikasi yang baik dengan keluarga dan mengetahui banyak sekali unsur negatif dari televisi tersebut, namun bapak $\mathrm{MH}$ pun jarang sekali melakukan komunikasi dengan anak saat ia sedang menonton televisi sendirian.

Dalam hal tayangan lain bapak MH sangat peduli terhadap anak yakni untuk tayangan berita-berita kriminal, bapak MH sangan melarang anaknya untuk melihatnya, sebagaimana dalam wawancara beliau mengatakan:

"Memang untuk acara film yang lain saya tidak memperdulikannya, tetapi saya selalu mengingatkan babkan melarang kepada anak WDT agar tidak menonton tayangan atau acara televise yang berkaitan dengan criminal atau kejehatan, teror ataupun sejenisnya, babkan bila tayangan tersebut sedang berlangsung dan anak sedang menonton maka saya langsung mematikan televisinya."(Wawancara dengan bapak MH pada tanggal 17 Januari 2018).

Dari hasil wawancara tersebut, bahwa bapak $\mathrm{MH}$ melarang anaknya untuk menonton berita kriminal, bapak MH melakukan hal ini karena khawatir dari tayangan tersebut anak dapat mengenal dan akhirnya menirukan apa yang dilihatnya dan kemudian mempraktekannya seperti peristiwa-peristiwa terjadi belakangan ini dimana seorang anak tega membunuh temannya cuma lantaran tersinggung. Oleh sebab itu bapak MH selalu memberikan pengertian dan senantiasa menasehati agar anak selalu berbuat baik kepada siapapun.

\section{Keluarga Bapak RLN dan Ibu SFY dengan Anak Bernama IBN}

Bapak RLN adalah kepala keluarga yang bekerja sebagai buruh bangunan yang senantiasa berpindah tempat dari satu daerah kedaerah lain, sedangkan ibu SFY adalah ibu rumah tangga, keluarga bapak RLN adalah keluarga harmonis yang mempunyai tiga orang anak, satu diantaranya adalah IBN yang berusia 10 tahun. Pada saat itu peneliti berkunjung dengan maksud melakukan wawancara dan pada saat itu pula bapak RLN sedang berada di rumah sedang menonton televise dengan anaknya, dan wawancara peneliti dengan bapak RLN berkaitan dengan permasalahan yang sedang diteliti, beliau mengatakan:

"Televisi sebenarnya bukan lagi hal yang baru, justru sekarang televisi bisa dikatakan menjadi kebutuhan pokok dalam keluarga, bukan hanya sebagai media informasi tetapi juga sebagai media biburan bagi keluarga. Kebiasaan menonton televisi bagi keluarga saya adalah hal yang lumrah, seperti anak saya kebiasaannya menonton televisi menjadikan dia tahu mana acara yang rame mana acara yang tidak rame sehingga kebiasaan ini menjadikan anak sulit untuk di nasehati bila sedang menonton tayangan yang rame itu walaupun sudah waktunya dia untuk istirabat tetap saja anak tidak mengindabkan ucapan ibunya, ya walaupun terkadang anak seperti itu tapi kami masib bisa

${ }^{19}$ Wawancara dengan bapak MH pada tanggal 16 Januari 2018 
mengarahkannya agar anak jangan sampai melihat sinetron-sinetron yang kira-kira tidak baik istilabnya kurang mendidik.." 20

Ibu SFY pun menambahkan:

"Kebiasaan anak menonton to memang tidak bisa dilarang, bila sedang asyik menonton dan waktu menontonya sudah hampir untuk dia mengaji saya selalu mengingatkannya dan begitu juga untuk waktu yang lainnya seperti belajar, sekolah dan istirahat. Hal ini kami lakukan untuk membiasakan anak bidup teratur jangan sampai terlalu cape dengan kegiatan main, nonton tv dan lain sebagainya." (Wawancara dengan ibu SFY, pada tanggal 20 Januari 2018).

Berdasarkan hasil wawancara tersebut, bapak RLN maupun ibu SFY senantiasa selalu memperhatikan kegiatan anaknya terutama dalam hal menonton televise, walaupun kegiatan anak dalam menonton dibebeaskan, tetapi bapak RLN maupun ibu SFY selalu memberikan pengertian agar anak tidak terlalu lama menonton dan selalu ibu SFY membagi waktu anak untuk kegiatan mengaji, belajar dan istirahat.

Dalam hal komunikasi bapak RLN yang sedang bekerja selalu meluangkan waktu istirahatnya berkomunikasi dengan keluarga baik isteri maupun anaknya, dalam hal ini bapak RLN selalu berpesan kepeda ibu SFY agar anak dibiasakan bila sudah waktunya mengaji dan belajar anak harus mengerjakannya. Dan begitupun dalam menonton televisi agar ibunya selalu mandampingi anak, sebagaimana dalam wawancaranya mengatakan:

"Kalau masalah mendampingi anak saat menonton saya jarang sekali karena kesibukan kerja tapi saya selalu menyempatkan saat istirahat kerja saya gunakan untuk berkomunikasi dengan keluarga lewat telpon baik dengtan isteri ataupun dengan anak, adapun untuk urusan rumab saya serabkan kepada ibunya ya salah satunya membimbing anak dan menemaninya saat menonton tv. Biasanya yang anak tonton itu film kartu kaya doraemon, sinchan dan lain-lain, tapi anak saya suka protes kalau acara yang ditonton itu seperti kuis-kuis tentang pengetahun itu dia gak suka terus digantinya dengan sinetron atau film kartun lainnya." 21

Berdasarkan wawancara di atas, bapak RLN sangat menjaga sekali komunikasi dengan keluaraganya terutama sekali dengan anak, karena bapak RLN menginginkan perkembangan anak tumbuh dengan baik, dan anak juga akan merasakan perhatian yang lebih dari orang tuanya oleh sebab itulah walaupun bapak RLN sibuk bekerja tapi tanggung jawab pekerjaan rumah ibu SFY yang menggantikannya sehingga kebutuhan anak akan perhatian orang tua terpenuhi.

Sebenarnya media televisi itu baik untuk anak kalau tayangannya yang mendidik dan secara langsung anak dapat bermain dan belajar dan tayangan yang mendidik itu juga sebagai sarana berkomunikasi anatara orang tua dan anak untuk senantiasa belajar dan mencari tentang hal yang belum diketahuinya seperti halnya tayangan yang menceritakan kisah-kisah atau legenda orang terdahulu yang sempat juga anak tanyakan kepada saya, hal yang demikian ini selalu terjadi dikarenakan satu sisi anaknya aktif satu

${ }^{20}$ Wawancara dengan keluarga bapak RLN, pada tanggal 20 Januari 2018.

${ }^{21}$ Wawancara dengan bapak RLN, pada tanggal 20 Januari 2018 
sisi lagi orang tua pun selalu dirumah nonton bersama dengan anak. Sebagaimana wawancara dengan bapak RLN:

"Sebenarnya tayangan yang mempungai unsur mendidiklab yang baik dan dapat di tangkap serta difahami oleh anak serta ditambah dengan menjalin komunikasi yang seimbang antara orang tua dan anak, ya walaupun saya jarang di rumah tapi komunikasi dengan keluarga terus berjalan karena bagi saya pribadi menjalin komunikasi dengan keluarga sangatlah penting, terutama sekali komunikasi dengan anak karena perkembangan anak itu sendiri merupakan tanggung jawab besar bagi orang tuanya, maka oleh karena itu saya selalu memberikan yang terbaik untuk anak saya terutama dalam hal memilibkean tontonnan yang baik.'22.

\section{Kesimpulan}

Dari pembahasan hasil penelitian yang telah dikemukakan dapat disimpulkan halhal sebagai berikut, Komunikasi orang tua terhadap anak dalam seleksi menonton televise Ngentak Sapen, Catur Tunggal, Depok, Yogyakarta bisa dikatakan berjalan dengan baik walaupun hanya sebagian dari para orang tua yang menyadari besarnya pengaruh televisi bagi perkembangan anak, terutama dalam ucapan dan prilaku. Sedangkan orang tua yang selebihnya lagi menganggap tayangan televisi untuk anakanak tidaklah perlu dikhawatirkan dan membiarkanya, terlebih lagi kesibukan orang tua juga yang menyebabkan anak dengan bebas untuk menonton film apapun.

Berbagai bentuk hambatan yang dialami para orang tua dalam menjalin komunikasi dengan anak adalah tidak terlalu sulit walaupun terkadang anak suka marah, membantah bila diperintah, tidak pernah mengerti kalu dinasehati tapi bagaimanapun hambatan tersebut orang tua bisa memahaminya dan mencarikan solusi untuk mengubah hambatan tersebut dan tidak lupa selalu memberikan nasehat agar sikap anak yang demikian tidak kembali terjadi. Sedangkan untuk anak yang penurut selagi orang tuanya bias memahaminya anak pun akan mudah untuk diarahkan dan dibimbing.

\section{DaftarPustaka}

Bulaeng, Andi , Metode Penelitian Komunikasi Kontemporer, Yogyakarta: Andi, 2004.

Departemen Agama RI, Alquran dan Terjemah, Bandung: CV. Gema Risalah Press, 1993.

Kriyantono, Rachmat, Teknik Praktis Riset Komunikasi, Jakarta: Kencana Prenada Media Group, 2006.

Kuswandi, Wawan, Komunikasi Massa Sebuab Analisis Media Televisi, Jakarta: PT Renika Cipta, 1996.

Moleang, Lexy J. Dr, M.A., Metode Penelitian Kualitatif, Bandung: PT Remaja Rosdakarya, 1999.

Qodir, Abdul, Metodologi Riset Kualitatif (Panduan Dasar Melakukan Penelitian Kualitatif), Palangka Raya, t.np., 1999.

Sobur, Alex Komunikasi Orang Tua dan Anak, Bandung: Angkasa, 1985.

${ }^{22}$ Wawancara dengan bapak RLN, pada tanggal 20 Januari 2018 